\title{
Roger Rocha
}

\section{Petroleum Supply Planning: Models, Reformulations and \\ Algorithms}

\section{TESE DE DOUTORADO}

DEPARTMENTO DE INFORMÁTICA

Postgraduate program in Informatics 


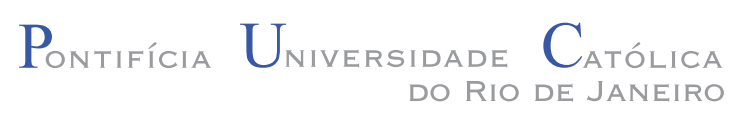

Roger Rocha

\section{Petroleum Supply Planning: Models, Reformulations and Algorithms}

Tese de Doutorado

Thesis presented to the Postgraduate Program in Informatics of the Departmento de Informática, PUC-Rio as partial fulfillment of the requirements for the degree of Doutor em Informática

Advisor: Prof. Marcus Vinicius Soledade Poggi de Aragão 


\title{
Pontifícia $U_{\text {niversidade }}$ Católica $_{\text {a }}$ DO RIO DE JANEIRO \\ Roger Rocha
}

\section{Petroleum Supply Planning: Models, Reformulations and Algorithms}

Thesis presented to the Postgraduate Program in Informatics of the Departmento de Informática do Centro Técnico Científico da PUCRio, as partial fulfillment of the requirements for the degree of Doutor. Approved by the following commission:

\author{
Prof. Marcus Vinicius Soledade Poggi de Aragão \\ Advisor \\ Departmento de Informática - PUC-Rio \\ Prof. Ruy Luiz Milidiú \\ Departamento de Informática - PUC-Rio \\ Prof. Silvio Hamacher \\ Departamento de Engenharia Industrial - PUC-Rio
}

Prof. Abilio Pereira de Lucena Filho

Departamento de Administração — UFRJ

Prof. Eduardo Uchoa Barboza

Departamento de Engenharia de Produção — UFF

Prof. Marcia Helena Costa Fampa

Departamento de Ciência da Computação — UFRJ

Prof. José Eugenio Leal

Coordinator of the Centro Técnico Científico da PUC-Rio 
All rights reserved.

\section{Roger Rocha}

Graduated from the Universidade Federal do Espírito Santo in Mechanical Engineering. He did part of his undergraduate studies at Ècole de Mines de Nancy (France) in the Decision Support and Production System Department. He then specialized at PETROBRAS University in Equipment Engineering - Petroleum Refining and Production Systems. He obtained a Master degree at COPPE-UFRJ in Computer Science and System Engineering. He has been working at PETROBRAS Research and Development Center since 2001 where he develops decision support tools for the business areas.

Bibliographic data

Rocha, Roger

Petroleum Supply Planning: Models, Reformulations and Algorithms / Roger Rocha; advisor: Marcus Vinicius Soledade Poggi de Aragão. — 2010.

124 f: il.; $29,7 \mathrm{~cm}$

1. Tese (Doutorado em Informática - Pontifícia Universidade Católica do Rio de Janeiro, Departmento de Informática, 2010.

Inclui bibliografia.

1. Informática - Teses. 2. Planejamento do Suprimento de Petróleo. 3. Programação Inteira. 4. Algoritmo de Decomposição. 5. Programação Disjuntiva. 6. Reformulações. I. Poggi de Aragão, Marcus V.S.. II. Pontifícia Universidade Católica do Rio de Janeiro. Departmento de Informática. III. Título. 
To my wife Renata, my father Jarbas and my mother Helena 


\section{Acknowledgments}

I would like to express my gratitude to my advisor Professor Marcus Vinicius Soledade Poggi de Aragão for his continuous support, advice and incentive during my research. His invaluable guidance was essential in all the time of research and writing of this thesis.

It is an honor for me having worked with Prof. Ignacio Grossmann at Carnegie Mellon University. My sincere thanks goes to him for accepting me as a visiting student and providing me excellent insights on mathematical modeling and solution techniques. Most of the chapters of this thesis are joint work with him.

I owe my deepest gratitude to PETROBRAS, for giving me the opportunity and time to carry over this research and allowing me to add this achievement to my career. In particular, I am grateful to my manager, Luiz Fernando de Jesus Bernardo, for his motivation, enthusiasm and friendship that always helped me to keep on working during hard times.

I also want to thank all my friends at the Logistic, Distribution and Transportation Department at PETROBRAS Research Center. They kept the ball rolling during the time I was out working for my thesis.

Last, but not least, I would like to show my gratitude to all fellows in my church for the spiritual support, specially during the time I was expatriated. 


\section{Resumo}

Rocha, Roger; Poggi de Aragão, Marcus V.S.. Planejamento do Suprimento de Petróleo: Modelos, Reformulações e Algoritmos . Rio de Janeiro, 2010. 124p. Tese de Doutorado Departamento de Informática, Pontifícia Universidade Católica do Rio de Janeiro.

A atividade de Planejamento de Suprimento de Petróleo é um elo importante para a integração da Cadeia de Suprimento de Petróleo na PETROBRAS, uma vez que é responsável por refinar as informações do planejamento estratégico a ser implementado no nível operacional. Nesta tese, esse problema é definido e explicado em detalhes e um modelo de programação Inteira Mista é proposto para resolvê-lo. Embora os resolvedores de problemas de programação Inteira Mista tenham evoluído de forma surpreendente na última década, para esta aplicação em particular, com o modelo inicial proposto não é possível obter soluções com qualidade satisfatória em tempo computacional aceitável. Desta forma, a linha de pesquisa desta tese consistiu em investigar, em detalhe, a estrutura deste problema a fim de encontrar reformulações mais adequadas e novos algoritmos para a solução deste problema. O foco principal desta tese é resolver de forma eficiente o problema de planejamento de suprimento de petróleo na PETROBRAS, no entanto, como subprodutos desse esforço são propostos um novo algoritmo de decomposição e reformulações que podem ser aplicados a uma ampla gama de problemas. No que diz respeito à realização do objetivo principal, todos os casos testados foram resolvidos de maneira eficiente através dos desenvolvimentos propostos. O novo algoritmo de decomposição se mostrou o método mais adequado para resolver as instâncias com mais de duas classes de navios operando em cada plataforma. Já para os casos com uma ou duas classes de navios, a formulação denominada Hull Relaxation, que tem como base uma estrutura definida neste trabalho como Cascading Knapsack Inequalities, é a melhor alternativa de solução. Tendo em vista estas alternativas de soluções, é implementado um algoritmo geral que automaticamente escolhe a melhor opção de solução, em função da estrutura do problema. Para a situação onde o número de classes de navios operando nas diversas plataformas varia entre um e quatro, pode-se usar mais de uma abordagem em paralelo e considerar como solução a alternativa mais rápida ou com melhor resultado. Este modelo está sendo testado na PETROBRAS e tem-se mostrado uma ferramenta eficaz para a integração de sua cadeia de suprimentos de petróleo, bem como permitindo a análise de cenários para a obtenção de soluções alternativas até então não exploradas. 


\section{Palavras-chave}

Planejamento do Suprimento de Petróleo; Programação Inteira;

Algoritmo de Decomposição; Programação Disjuntiva; Reformulações. 


\section{Abstract}

Rocha, Roger; Poggi de Aragão, Marcus V.S.. Petroleum Supply

Planning: Models, Reformulations and Algorithms. Rio de Janeiro, 2010. 124p. DSc Thesis - Departamento de Informática, Pontifícia Universidade Católica do Rio de Janeiro.

The Petroleum Supply Planning activity is an important link for the integration of the Petroleum Supply Chain at PETROBRAS as it is responsible for refining the strategic supply planning information to be used at the operational level. In this thesis we set the ground for understanding this important problem and we propose a mathematical model to solve it. Although the solvers in the last decade have evolved enormously, for this particular application we cannot get solutions with satisfactory quality in reasonable computational time with only the initial proposed model. This directed the line of research of this thesis into investigating, in detail, the structure of this problem in order to find more suitable reformulations and algorithms to tackle it. Our primary goal is to solve efficiently the petroleum supply planning problem at PETROBRAS. Nevertheless as a by-product of this endeavor, we propose a novel decomposition algorithm and reformulations based on a cascading knapsack structures that turn out to be applicable in a wide range of problems. Concerning the achievement of the main objective, we obtain good results for all instances we tested. We show that the novel decomposition algorithm is the most fitted method to solve the petroleum supply planning problem if we consider more than two tankers to offload each platform. In the case of one or two tankers to offload each platform, the hull relaxation formulation based on the cascading knapsack structure introduced after an inventory reformulation at platforms is the best option if one is to solve this problem. For the real application, these solution alternatives allow to implement a general algorithm that automatically switches to the best solution option depending on the structure of the problem. For the mixed situation, i.e., number of tanker varying from one to four, one can use more than one approaches in parallel and take the fastest or the best result obtained. This model is being tested at PETROBRAS and is showing to be an effective tool to help integrate its petroleum supply chain as well as to do what-if analysis to look for alternative solutions never thought before.

\section{Keywords}

Petroleum Supply Planning; Integer Programming; Decomposition Algorithm; Disjunctive Programming; Reformulations. 
Contents

1 Introduction $\quad 14$

$\begin{array}{lll}1.1 & \text { Thesis Organization } & 16\end{array}$

2 Problem Description $\quad 18$

2.1 Production Sites 19

$\begin{array}{ll}2.2 & \text { Tanker Fleet } \\ 2.30\end{array}$

2.3 Petroleum Category 20

2.4 Maritime Terminals 21

$\begin{array}{lll}2.5 & \text { Pipelines } & 22\end{array}$

2.6 Refineries 22

2.7 Problem Statement 22

3 Mathematical Model $\quad 24$

3.1 Solution Example $\quad 31$

3.2 Flexibility of Campaigns 33

$\begin{array}{ll}3.3 & \text { Changeover Cut } \\ \end{array}$

4 Decomposition Algorithms $\quad 39$

$\begin{array}{lll}4.1 & \text { Summary } & 39\end{array}$

4.2 Dantzig and Wolfe Decomposition 40 Column Generation $\quad 41$

4.3 Benders Decomposition 44

4.4 Lagrangean Relaxation $\quad 48$

Lagrangean Decomposition $\quad 50$

5 A Novel Decomposition Algorithm 52

5.1 Summary $\quad 52$

5.2 The Basic Idea $\quad 53$

Cut Generation $\quad 54$

Separation problem $\quad 55$

Normalization $\quad 56$

Upshot of the algorithm $\quad 57$

$\begin{array}{lll}5.3 & \text { Improved Idea } & 58\end{array}$

$\begin{array}{ll}\text { Local Branching } & 59\end{array}$

Repairing MIP infeasibility 62

5.4 Computational Experiments 64

Generalized Assignment problem 64

Parallel Machine Scheduling problem 66

$\begin{array}{lll}5.5 \text { Conclusions } & 71\end{array}$ 
6 Cascading Knapsack Inequalities: Hidden Structure in some Inventory-Production-Distribution Problems $\quad 72$

$\begin{array}{lll}6.1 & \text { Summary } & 72\end{array}$

$\begin{array}{lll}6.2 & \text { Introduction } & 73\end{array}$

Initial Mathematical Formulation $\quad 75$

Inventory balance Reformulation $\quad 76$

6.3 Simplified Case: Only one class of tanker 78

$\begin{array}{lll}6.4 & \text { Two classes of tankers } & 80\end{array}$

Hull Relaxation Formulation $\quad 87$

$\begin{array}{lll}6.5 & \text { Computational Study } & 90\end{array}$

Discussion of Results 94

$\begin{array}{lll}6.6 & \text { Conclusions } & 96\end{array}$

$7 \quad$ On the Solution of the Petroleum Supply Planning $\quad 97$

$\begin{array}{lll}7.1 & \text { Summary } & 97\end{array}$

7.2 Inventory Balance Reformulation at Production Sites 98

$\begin{array}{lll}7.3 & \text { Valid Inequalities } & 99\end{array}$

Example 103

$\begin{array}{lll}7.4 & \text { Extended formulation } & 105\end{array}$

$\begin{array}{lll}7.5 & \text { Decomposition Algorithm } & 106\end{array}$

$\begin{array}{lll}7.6 & \text { Computational Results } & 107\end{array}$

$\begin{array}{lll}7.7 & \text { Conclusions } & 113\end{array}$

8 Conclusions $\quad 114$

$\begin{array}{lll}8.1 & \text { Thesis Contributions } & 115\end{array}$

$\begin{array}{lll}8.2 & \text { Future Work } & 116\end{array}$

$\begin{array}{lr}\text { Bibliography } & 118\end{array}$ 
List of Figures

1.1 Infrastructure of PETROBRAS' Petroleum Supply Chain

2.1 Simplified Hierarchical Structure of the Petroleum Supply Chain at PETROBRAS

2.2 Schematic of the Campos Basin production area - Source: PETROBRAS

2.3 Schematic of the storage capacity assigned to the refineries connected to the São Sebastião terminal in São Paulo - The rectangles between refineries represent the tanks shared by them 21

2.4 Connection between terminals and refineries 23

3.1 Schematic representation of the inventory in a given refinery 29

3.2 Summary of offload scheduling at Platform P1

3.3 Summary of the inventory and discharging activity at Terminal T1

3.4 Summary of the inventory levels at Refinery R1 33

3.5 Flexibility of Campaigns at Refineries 34

3.6 Comparison between the inventory evolution of category c1 at refinery r1 using initial and flexible campaigns

3.7 Comparison between the inventory evolution of category $\mathrm{c} 1$ at refinery r2 using initial and flexible campaigns

3.8 Motivated example to justify the changeover cuts

4.1 Comparison between Relaxations and the $(I P)$ optimum solution $v(I P)$

5.1 Possible outcome of different normalizations

5.2 Comparison between the proposed cut and the canonical cut

5.3 Possible limitation of the proposed algorithm 60

5.4 Basic Tree representation of the Local Branching procedure 61

5.5 Effect of the problem matrix condition number on the optimum solution found

6.1 Schematic representation of the problem 74

6.2 Network Flow representation of the reformulation 81

6.3 Integer 2-Commodity Network Flow representation of the reformulation 83

6.4 Convex hull of the pair of Knapsack inequalities 84

6.5 Illustration of the algorithm to calculate the convex hull of a 2 integer knapsack

7.1 Representation of the algorithm to obtain the upper bound on the number of tankers that can visit a platform $p$

7.2 Representation of the algorithm to obtain the lower bound on the number of tankers that can visit a platform $p \quad 101$

7.3 Basic idea of the extended formulation 
$\begin{array}{lll}7.4 & \text { Decomposition Scheme } & 107\end{array}$

8.1 Petroleum Supply Planning System - ALOPE 114 
List of Tables

3.1 Dimension of test instances 37

3.2 Computational results for solving instance 1 using changeover cuts 37

3.3 Computational results for solving instance 2 using changeover cuts 38

3.4 Computational results for solving instance 3 using changeover cuts

5.1 Computational results for the Generalized Assignment 66

5.2 Characteristic of the instances 68

5.3 Computational results for the Parallel Machine Scheduling 69

5.4 Comparison of cuts generated from different decomposition $\begin{array}{ll}\text { algorithm } & 70\end{array}$

6.1 Extreme points of the Relaxations $\quad 89$

6.2 Comparison of LP relaxation 91

6.2 (Continued) 92

6.3 Results for one class of tanker for all platforms and terminals 93

6.4 Results for one class of tanker for each platform, however it can be different from platform to platform $\quad 93$

6.5 Results for two classes of tankers 94

7.1 Comparison of linear relaxations for more than two classes of

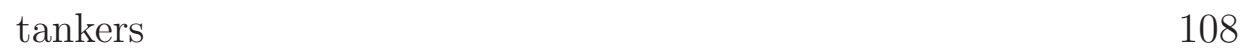

7.2 Comparison of linear relaxations for two classes of tankers 109

7.3 Comparison of linear relaxations for one class of tanker 109

7.4 Comparison of all different models for more than two classes of tankers 110

7.5 Comparison of all different models for two classes of tankers 110

7.6 Comparison of all different models for one class of tanker 110

7.7 Comparison of the Best Formulation and the Novel Decomposition for more than two classes of tankers 112

7.8 Comparison of the Best Formulation and the Novel Decomposition for two classes of tankers 112

7.9 Comparison of the Best Formulation and the Novel Decomposition for one class of tanker 